\title{
Glacial erratics on the Arctic Ocean margin of North Greenland: implications for an extensive ice-shelf
}

PETER R. DAWES

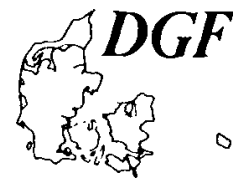

\begin{abstract}
Dawes, P. R.: Glacial erratics on the Arctic Ocean margin of North Greenland: implications for an extensive ice-shelf. Bull. geol. Soc. Denmark, vol. 35, pp. 59-69, Copenhagen, October, 29th, 1986. https://doi.org/10.37570/bgsd-1986-35-07

Glacial erratics of high-grade metamorphic and plutonic rocks occur on the northern coast of Peary Land on the edge of the Arctic Ocean. Crystalline terrain is not exposed in Peary Land; sample sites are $250 \mathrm{~km}$ distant from the present-day Inland Ice which covers the nearest potential source - the Greenland shield. The dominant till clasts are locally derived from a northem ice-cap that coalesced during the late Wiscon- sinian glacial maximum with the Inland Ice at about $82^{\circ} 30^{\prime} \mathrm{N}$.

Recent Quaternary mapping by the Geological Survey of Greenland failed to locate crystalline erratics in northernmost Peary Land; consequently prominence is given to early observations. The present paper describes a collection of erratics made in 1969. Conveyance mechanisms, viz. ice-cap regime (glacier or ice-shelf) contra drifting ice (icebergs or sea ice) are discussed and possible transportation paths are summarised.

Based on rock type and mineralogy, the Greenland shield is the most likely source of the erratics and derivation from an expansion of the Inland Ice around eastern Peary Land the most logical glacial model. However, such a provenance contravenes with the presently available on-shore data which indicate an eastwards Weichselian ice flow along the coast. Instead of invoking a rather complicated glacial history for Peary Land, involving different land ice regimes, an alternative glacial model based on an extensive Greenland - Ellesmere Island ice-shelf is outlined.
\end{abstract}

P. R. Dawes, Grønlands Geologiske Undersøgelse, Øster Voldgade 10, 1350 Copenhagen K, Denmark. January 15th, 1986

The implications of certain glacial erratics on the outer coast of Peary Land is the subject of a paper in this journal by Funder \& Larsen (1982). These authors were primarily concerned with volcanic erratics that occur on Earth's most northerly islands, Kaffeklubben $\varnothing$ and Oodaaq $\emptyset$ and more sporadically on nearby coastland (Figs. 1, 2). The erratics were referred to the late Cretaceous Kap Washington Group, onshore outcrops of which occur to the west of the erratic sites (Larsen, 1982). This led to the suggestion that an easterly directed Weichselian glacial force must have existed along the coast. In a concluding remark Funder \& Larsen (1982) refer to the peculiar occurrence of granite and gneiss erratics reported by Koch (1923a,b) and Dawes (1970) along the same coast. Crystalline erratics were not found by Funder \& Hjort (1980) during recent regional Quaternary studies, and Funder \& Larsen (1982, p. 60) conclude that "the reported occurrence of these erratics remains a mystery."

This paper documents the discovery of the crystalline erratics; the rocks are briefly de- scribed and the implications in terms of provenance and ice conveyance are discussed.

\section{Glacial erratics and ice regimes}

The gross distribution pattern of glacial erratics in northern Greenland (Kane Basin to Wandel Sea - Fig. 1) was determined by Lauge Koch. Adding to observations by Bessels (1879) and Feilden (1895) in the west and I. P. Koch (1916) in the east, Koch (1923a,b, 1928a,b) noted the contrast in the till clast composition between Peary Land and land to the west. In the west a heterogeneous erratic block assemblage containing both local and far-travelled elements including characteristic Proterozoic and Lower Palaeozoic rocks, as well as gneiss and granite, covers the entire area from the Inland Ice to the outer coast; in contrast, Peary Land can be divided into a southern province covered by a similar heterogeneous till and a northern province characterised by locally-derived clasts. 


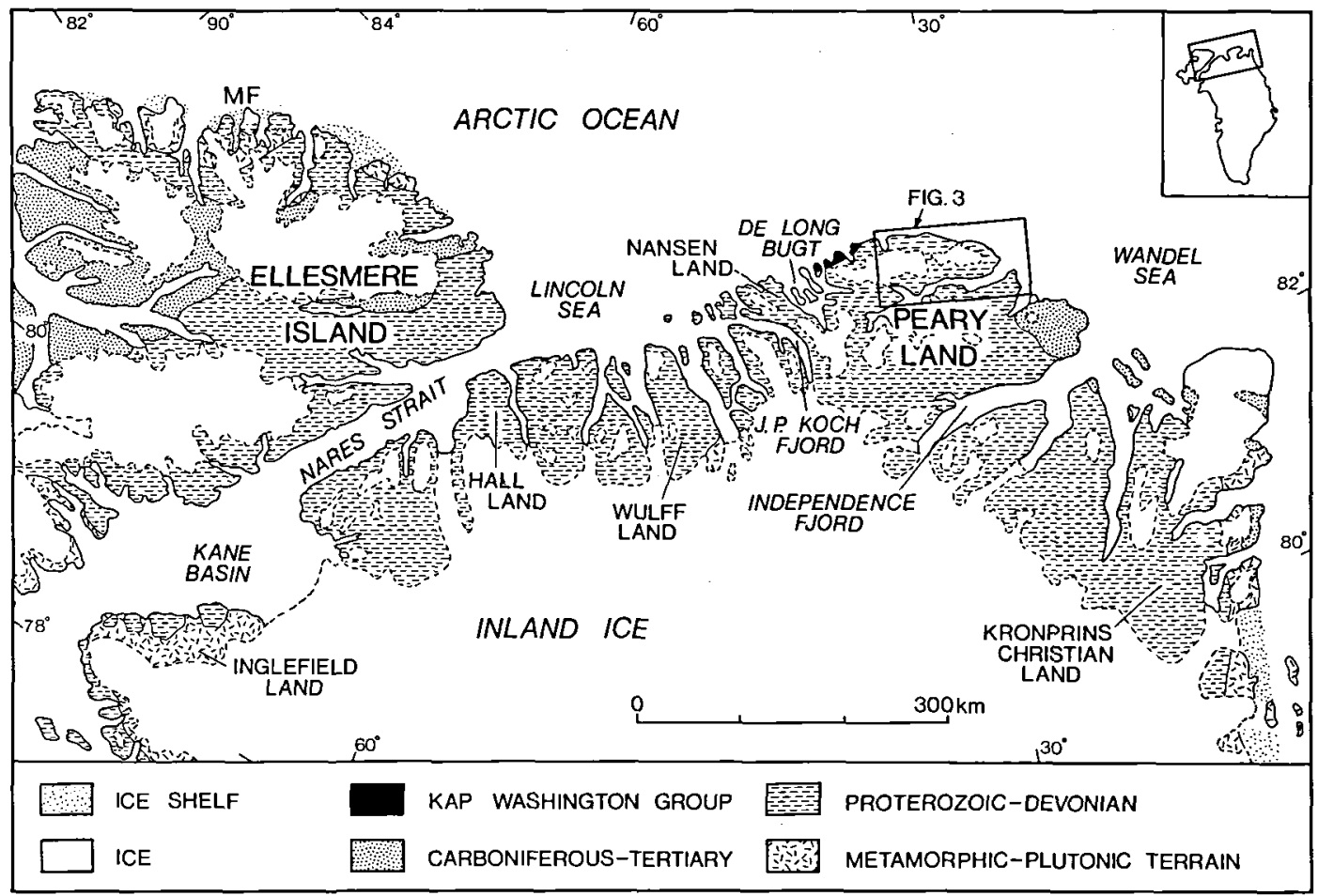

Fig. 1. Locality and geological map of northern Greenland and adjacent Ellesmere Island showing main outcrops of metamorphicplutonic terrain (potential source of crystalline glacial erratics) and other geological provinces. MF $=$ Milne Fiord. Greenland geology from GGU publications; Canadian geology from Frisch (1974), Trettin \& Balkwill (1979) and Survey and Mapping Branch, map of Robeson Channel, 1:1 000000 from 1975.

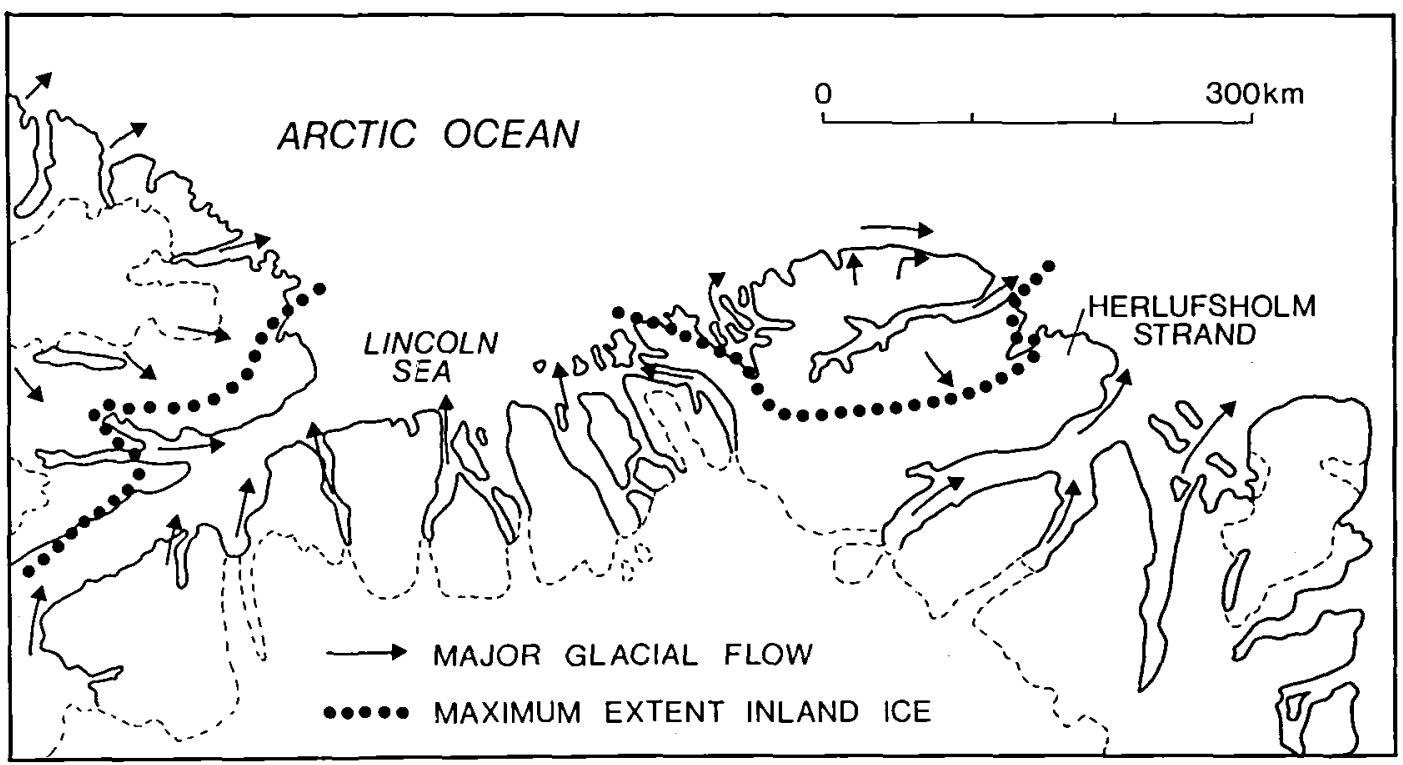

Fig. 2. Map showing the maximum extension of the late Wisconsinian-Weichselian Inland Ice forming ice shelves in Lincoln Sea and Wandel Sea, and suggested main glacial flow directions. Compiled from published sources mentioned in text; position of boundary in northern Nansen Land (see fig. 1) after O. Bennike (pers. comm.). 
Koch $(1920$, p. 13) observed a predominance of crystalline erratic boulders near the Inland Ice margin confirming their southerly provenance from the shield that he assumed underlay the ice joining the then known outcrops in Inglefield Land (L. Koch, 1933) and Kronprins Christian Land (I. P. Koch, 1916; Mikkelsen, 1922). The most northerly outcrops of the shield are now known to be in southern Wulff Land (Fig. 1).

Koch $(1923 a, b)$ concluded that during the time of maximum ice coverage, the Inland Ice reached the Arctic Ocean in the west and as far north as about $82^{\circ} 45^{\prime} \mathrm{N}$ in the east, south of a line from inner J. P. Koch Fjord to outer Independence Fjord. Koch projected this line for $300 \mathrm{~km}$ across Peary Land from coastal observations in the west and east. Not surprisingly the detailed position and precise nature of the boundary line have been modified (Troelsen, 1952; Davies, 1963; Christie, 1975; Weidick, 1976; Funder \& Hjort, 1980), but the concept that northernmost Peary Land was not overridden by the Inland Ice has been upheld (Fig. 2). Northernmost Peary Land comprises a mountainous region with alpine peaks over $1000 \mathrm{~m}$, the highest of which in the Roosevelt Fjelde reaches about $1900 \mathrm{~m}$.

Summarising, there is general consensus that during the glacial maximum northernmost Greenland was influenced by two main glacial regimes: a southern ice accumulation derived by expansion of the Inland Ice, and an independent northern ice cap centred on the mountainous areas around Frederick E. Hyde Fjord. These accumulations were confluent in central Peary Land. In the west the Inland Ice traversed Nares Strait to a distance of more than $100 \mathrm{~km}$ from its present-day position to become confluent with the Ellesmere Island ice sheet (Fig. 2, Christie, 1967; England \& Bradley, 1978). In the east the Inland Ice extended over eastern Peary Land to form an ice-shelf in the Wandel Sea; along the northern coast a piedmont glacier is envisaged formed by coalescence of outlet glaciers from the northern ice cap (Davies, 1963; Funder \& Hjort, 1980; Funder \& Larsen, 1982).

\section{Discovery of crystalline erratics}

The discovery of crystalline erratics along the northern coast of Peary Land was made by Lauge
Koch during his dog-sledge traverse in 1921. However, reference to these erratics is restricted to a few sentences; "several blocks of granite"“occasional granitic boulders" (Koch, 1928a, p. $504 ; 1928$ b, p. 376). No samples were apparently brought home and the precise observation sites are unknown; a location in 'Peary Land proper', somewhere between De Long Bugt and Kap Ole Chiewitz, can be gleaned from Koch (1920, 1923a,b, 1928a,b).

The granitic erratics were regarded as derived from a high-grade core or nucleus of the "Caledonian' fold belt which Koch assumed formed the interior of the alpine mountains of Johannes V. Jensen Land (Fig. 3). Such a high-grade nucleus is now known to be non-existent (see Ellitsgaard-Rasmussen, 1955 , p. 48 , for discussion); the metamorphic grade of the North Greenland fold belt is generally low, it increases gradually northwards reaching low amphibolite facies at the outer coast (Dawes \& Soper, 1973; Soper et al., 1980).

Davies (1963) records a 'gray gneiss' in stone counts along the outer coast at Kap Moris Jesup, Kaffeklubben $\emptyset$, Kap Ole Chiewitz and Skagen forming between 2 and 30 percent of the clasts. It should be noted that this rock term covers pale weathering low-grade psammites and phyllites that are derived from the exposed sequences of northern Peary Land (W. E. Davies, pers. comm.). Davies noted the widespread occurrence of a pink granite in the heterogeneous till south of the maximum extension line of the Inland Ice. Neither this granite nor other granitic or high-grade gneiss types were observed by Davies along the outer coast, but he recorded such rocks in eastern Peary Land as far north as Skagen where a 'red granite gneiss' makes up 2 percent of a stone count.

\section{Distribution of erratics}

A variety of crystalline erratics was noted by the present author in 1969 along the coast between Kap Ole Chiewitz and Henson Bugt (Fig. 3). The coast east of Sands Fjord forms a low-lying plain covered by Quaternary deposits: drift, moraines, marine silts and glacio-fluvial gravel. Bedrock exposures are rare. The plain is limited to the south by a fault scarp that borders the high ice- 


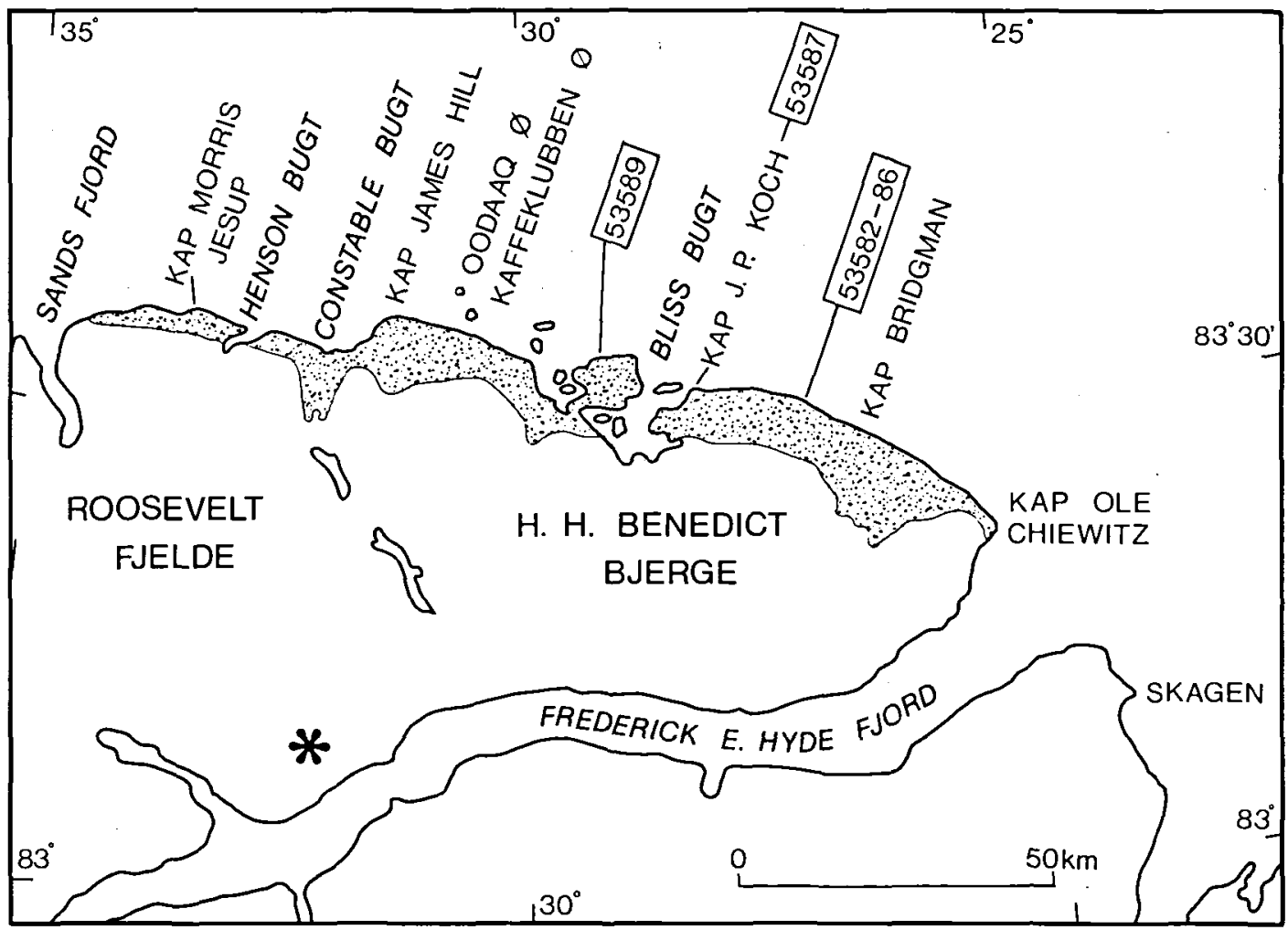

Fig. 3. Locality map of eastern Johannes V. Jensen Land showing sample sites of crystalline erratics and main area of surficial deposits (stippled). The star indicates general area of volcanic centers with crystalline enclaves (after Soper et al., 1980).

capped mountains of Roosevelt Fjelde and H. H. Benedict Bjerge (Fig. 4).

The observations on erratics were made during a skidoo traverse from Frederick E. Hyde Fjord to Kap Morris Jesup (Peacock, 1972). No systematic investigation of the surficial deposits was undertaken and no stone counts were made. Seven small fist-size samples were collected - GGU 53582-87, 53589. Conclusions on erratic block distribution made during what was essentially a one-way forced trek along a narrow strip of the coastal plain, must be treated with caution. However, some general inferences are given.

The crystalline erratics appear to be commonest at the outer coastal fringe of the plain. Many were noted in reworked moraine near or at sea level; some occur several metres above sea-ice level. Abundance of erratics generally decreases inland; several blocks were seen $150-200 \mathrm{~m}$ from the shore, but none inland, for example at or near the fault scarp to the mountains.

Crystalline erratics were seen more frequently east of Kap James Hill than, for example, in the west in the Kap Morris Jesup - Constable Bugt area. This may not be geologically significant but could reflect the incidental nature of the observations. However, no crystalline erratics were found at Kap Morris Jesup despite several days sojourn in the area; the westernmost erratics noted were at Henson Bugt.

In the east, where erratics were sampled, distribution is irregular; at several localities crystalline erratics were not located or were rare; elsewhere they can form a notable part of the till clast composition. For example, at locality $\mathbf{5 3 5 8 2}$ sizeable crystalline erratics are so conspicuous that they were used to construct a depot cairn.

\section{Till-clast composition}

Along the outer coast, crystalline erratics are the only till clasts observed that cannot be referred to local bedrock. [One small piece of pale limestone 


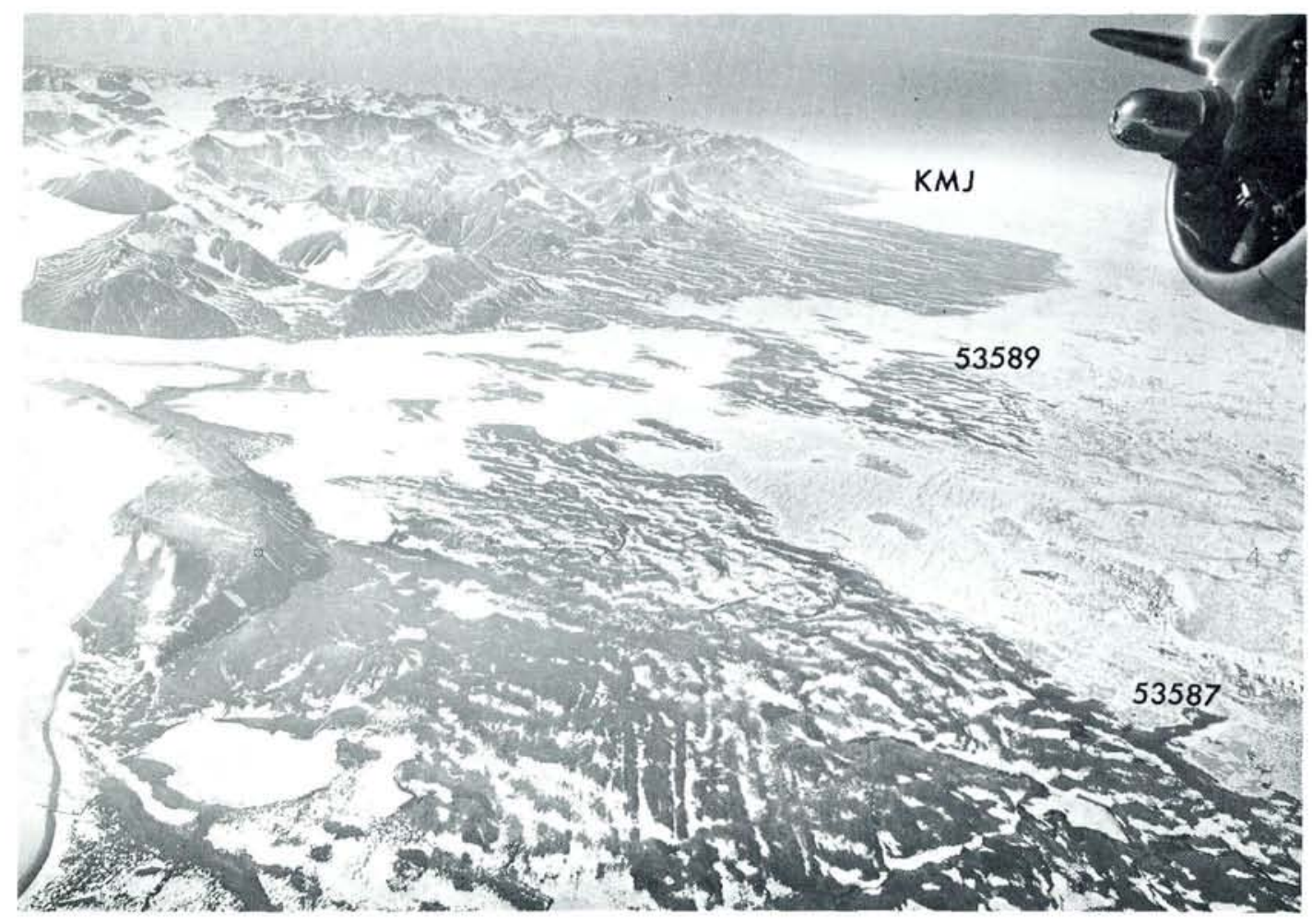

Fig. 4. Westerly view over the outer coast of Peary Land at Bliss Bugt showing the low-lying coastal plain backed by Roosevelt Fjelde. Two glacial erratic sample sites are shown. Kap Morris Jesup (KMJ) in distance. Aerial photograph 548 H-Y, 8857, July 1950, copyright Geodetic Institute, Denmark.

containing bryozoa and coral was also found near sample site 53582 by an expedition member in 1969 , but was not retained. Potential sources could be Carboniferous-Tertiary sequences of eastern Peary Land of Sverdrup Basin deposits of Ellesmere Island (Fig. 1)]. Crystalline erratics form a subsidiary component of the till. However, in many places they are conspicuous since they tend to form much larger clasts than the locally-derived sedimentary rocks.

The local erratics are non-metamorphic to lowgrade arenaceous rocks, predominantly psammites, grits and conglomerates, with chloritemica phyllites and occasional dark calcareous arenites and impure carbonates. Dark grey to black igneous rocks also occur, in places forming a dominant clast component. Main types are dolerite, gabbro and fine-grained volcanic rocks. In one area, to the east of Kap J. P. Koch, basic rocks are so prominent as to suggest in situ exposure.

The crystalline erratics range from $\mathrm{cm}$-size pebbles to cobbles and boulders; the largest boulder noted was about $2 \mathrm{~m}$ on its longest side. All have sub-rounded to rounded shapes with smooth, ice-water polished surfaces. A variety of rock types occur (see below); at some localities, for example sample site 53589 (Fig. 2), a particular rock type, in this case a red granite, predominates over other crystalline rocks; at other localities a range of types occur.

\section{Crystalline rock types}

The crystalline clasts of the till are composed of metamorphic and plutonic rocks, mainly gneisses and granites with migmatites and pegmatitic varieties, and lesser amounts of metabasic rocks, amphibolites and metagabbro. Many of the acidic rocks are reddish weathered; pegmatitic roeks are characterised by pink-red feldspars. The granites observed are fine to medium-grained, homogeneous to foliated; the gneisses vary from 
rather homogeneous to veined and crudely banded varieties, with some augen and porphyroblastic types.

The seven rocks in the present collection are briefly described below.

\section{Sample GGU 53582}

Grey medium-grained biotite gneiss composed of a dark grey equigranular gneissic palaeosome veined by $\mathrm{cm}$-scale pinkish weathered, leucocratic veins. Essential minerals are brown to greenish-brown biotite, plagioclase, $K$. feldspar, quartz with some myrmekite. Sphene, apatite are common accessories; ore, muscovite and epidote are minor. Plagioclase is patchily turbid and moderately saussuritised; $\mathbf{K}$. feldspar, mainly microcline is generally fresh. Quartz varies from small rounded grains included in feldspar to matrix grains commonly with sutured boundaries to, in the leucosome, large crystals showing prominent undulose extinction.

\section{Sample GGU 53583}

Pinkish, medium-grained biotite granitic gneiss composed essentially of biotite, microcline perthite, plagioclase and quartz. $\mathrm{K}$. feldspar is dominant over plagioclase; quartz is in intergrowths with both microcline and plagioclase. Accessories are apatite, zircon, with lesser amounts of sphene, muscovite and ore. Plagioclase is slightly saussuritised, typically along twin planes, microcline is fresh.

\section{Sample GGU 53584}

Pale grey, medium-grained, biotite, leucocratic gneiss. Plagioclase and quartz are the main felsic minerals; $K$. feldspar, mainly microcline, is subsidiary. Greenish-brown biotite is the main mafic giving a schistosity to the rock, but hornblende and clinopyroxene grains are present. Main accessories are apatite, sphene and ore, with minor epidote and muscovite. Plagioclase is commonly poikilitic containing rounded quartz grains; it varies from fresh to slightly saussuritised with calcite and epidote as main constituents. Biotite is slightly replaced by penninite.

\section{Sample GGU 53585}

Red, medium-grained, biotite, granitic gneiss with feldspar porphyroblasts. Essential minerals are biotite (brown to green), plagioclase, K. feldspar, mainly perthitic microcline, and quartz, with some myrmekite. Accessories are sphene, apatite, zircon, hornblende and ore; sphene characteristically rims $\mathrm{Fe}-\mathrm{Ti}$ oxide grains. Plagioclase varies from fresh to turbid with heavy saussuritisation, microcline is generally fresh, quartz varies markedly in grain size and displays mortar texture.

\section{Sample GGU 53586}

Black, medium-grained schistose amphibolite composed essentially of hornblende, biotite and plagioclase, with some quartz. Accessories are apatite, sphene and ore. Hornblende is the dominant mafic; large crystals can be poikilitic enclosing rounded quartz and plagioclase grains. Larger plagioclase crystals are slightly saussuritised.

\section{Sample GGU 53587}

Pink, medium-grained, equigranular granite composed essentially of biotite (brown to green), K. feldspar, mainly perthitic microcline, plagioclase and quartz. Myrmekite is common. Accessories are zircon and apatite. Large fresh $\mathrm{K}$. feldspar grains can contain quartz, plagioclase and biotite as inclusions; plagioclase varies from fresh to moderately saussuritised. Quartz varies from large crystals showing undulose extinction to interstitial grains and small rounded grains in feldspar.

\section{Sample GGU 53589}

Pink, fine to medium-grained leucogranite composed essentially of $\mathrm{K}$. feldspar, both orthoclase and microcline, plagioclase and quartz. Biotite, brown to green, forms the minor mafic component; this is in places altered to chlorite. Apatite, epidote and small ore grains are accessories. Plagioclase is characteristically turbid and saussuritised and often replaced by muscovite. K. feldspar is perthitic, Quartz occurs in intergrowths with both plagioclase and K. feldspar.

The characteristic mineral assemblage of the rocks is $K$. feldspar biotite-plagioclase-quartz; the one basic rock in the collection has a hornblende-biotite-plagioclase-quartz assemblage. The rocks form an amphibolite-facies graniticgranodioritic metamorphic-plutonic suite with basic meta-igneous components. The acidic types are characterised by having two-feldspars and a rather narrow mineralogical composition. Several rocks show evidence of retrogression with the replacement of biotite and amphibole and alteration of plagioclase.

\section{Potential source areas}

Potential source areas for the erratics are areas of crystalline rocks surrounding the Arctic Basin, and islands of the Barents Sea. The erratics do not possess diagnostic character or exotic mineralogy that pinpoint any one of these areas as the definite source; all above-mentioned terrains contain high-grade metamorphic-plutonic complexes.

However, the erratics do form a discrete metamorphic-plutonic suite characterised by a very narrow mineralogical range and a common metamorphic grade. This, and the apparent lack of other rock suites, strongly suggest that the source region is composed of rather limited geological terrains. The most likely candidates are the proximate areas of the Greenland shield, $250 \mathrm{~km}$ to the south and crystalline rocks that lie twice 
that distance to the west in northern Ellesmere Island (Fig. 1). The closest crystalline outcrops are in fact only $50 \mathrm{~km}$ distant on the north side of Frederick E. Hyde Fjord where a group of intrusive centres contain blocks of continental crust including gneiss and amphibolite (Soper et al., 1980, see Fig. 3). Size, location and lack of granites exclude these outcrops as a source area.

Based on general character and mineralogical composition, the Greenland shield appears to be the most suitable of the two most likely sources. Koch $(1928$ b, p. 376) states that the granitic erratics he discovered are "of different character" to the erratics derived from the shield. Such distinctive erratics were not seen by this author; all rocks in the present collection are similar to the bulk of the gneiss-granite-amphibolite clasts of the south. One sample (GGU 53587), a pink microcline perthite leucoadamellite, is similar to clasts in the till of Hall Land (Dawes, 1986) and to Davies' (1963) 'pink granite'. The exposed shield is composed of an amphibolite facies granodiorite orthogneiss-granite complex (Henriksen \& Jepsen, 1985).

High-grade rocks also characterise the outer coastal part of the Cape Columbia complex and related rocks of northernmost Ellesmere Island; greenschist facies terrain occurs inland (Frisch, 1974). Amphibolite facies biotite gneisses, amphibolites and two-feldspar granitic rocks form parts of the complex. On the other hand, a wide diversity of rock types occur, including distinctive mafic-ultramafic rocks and syenite-monzonite plutons; types not discerned in the Greenland erratic assemblage.

\section{Conveyance: ice-cap or drifting ice}

The crystalline erratics could have been transported either by an ice cap regime (glaciers or iceshelf) or by drifting ice (icebergs, sea ice or ice-islands). The marine limit between Kap Morris Jesup and Kap Ole Chiewitz is between 35 and 55 $m$ (Funder \& Hjort, 1980). The erratics occur below the level of marine submergence; theoretically the blocks could have been conveyed by floating ice. As such the erratics might "have been carried long distances across the Arctic Ocean and represent the high-grade rocks of another land mass" (Dawes, 1970). The well-known presence of 'Siberian' driftwood on the active and raised beaches around Peary Land indicates that circulation in the Arctic Basin has allowed for this possibility throughout glacial isostatic rebound. Moreover both the sea ice and glacial ice forming the present-day perennial cover of the Arctic Ocean, transport a significant sediment load; coarse debris, including cobbles and boulders, are fairly common in the glacial ice that forms parts of the Arctic ice pack (Clark \& Hanson, 1983).

If the erratics represent long-range rafted lag deposits it might be expected that a varied rock assemblage, representing the diverse geology of part of the Eurasian coast, would be present. This is not the case; there is, for example, an apparent lack of non-Greenlandic Phanerozoic rocks. The presence of ice rafted blocks cannot be excluded on this criteria alone, but any conveyance by floating ice may have been of more localised nature, i.e. along the Greenland-Ellesmere shore.

One possibility, involving floating ice, is that the erratics could have been derived from the Greenland shield behind the head of Independence Fjord and transported to their present site by icebergs in the early Holocene (Ole Bennike, pers. comm.). Academy Gletscher at the head of this fjord is today very productive seen in relation to North Greenland glaciers in general; whether this part of the Inland Ice margin was so in the early Holocene is unknown. Such a mechanism might explain both the easterly decrease in abundance of erratics along the outer coast and the apparent absence of far-travelled Greenlandic Proterozoic-Phanerozoic blocks, i.e. the bedrock under the present Inland Ice margin may primarily be composed of crystalline rocks without Phanerozoic cover. However, the theory demands a major and fairly consistent northerly current flow through the Wandel Sea; a contrast to the current pattern of the present day. The presence of driftwood eastern Peary Land deep up the fjords demonstrates a 'normal' circulation from the Arctic Ocean since about 6000 B.P.

Many of the erratics appear to be an intrinsic part of the ground moraine and while this has been reworked by marine and glacio-marine processes, it perhaps is more likely that the erratics have been transported by a glacial ice regime that deposited a drift cover. 


\section{Provenance}

Suggested transportation paths for the crystalline erratics are summarised in Table 1. During the glaciation maximum, valley glaciers spread northwards from the alpine-type mountains of Roosevelt Fjelde onto the coastal plain where they merged into a piedmont glacier which, according to Davies (1963, p. 103), "was probably similar in form to the shelf ice on the north side of Ellesmere Island." Similar outlet glaciers occurred on the east side of the ice cap; a major ice stream flowed down Frederick E. Hyde Fjord where it presumably coalesced with, and contributed to, the Wandel Sea ice shelf. This was formed by the north-eastern expansion of the Inland Ice down the major fjord depressions about $82^{\circ} \mathrm{N}$. Funder \& Hjort (1980) traced crystalline erratics of southerly provenance up to northern Herlufsholm Strand; Davies (1963) reported a 'red granite gneiss' at Skagen, $50 \mathrm{~km}$ farther north (Fig. 3). Skagen is only $25 \mathrm{~km}$ south of Kap Ole Chiewitz where erratics described in this paper occur.

Thus crystalline erratics occur, albeit rather patchily, all along the coast between Indepen- dence Fjord and Henson Bugt. This led Dawes (1972) to suggest the expansion of a northern lobe of the Inland Ice around eastern Peary Land; a model used by Weidick (1975) in estimates of Wisconsinian ice sheet expansion.

However, recent work by Funder \& Hjort (1980) and Funder \& Larsen (1982) based on the distribution of volcanic erratics, and supported by the morphology of moraines, kame terraces and glacial meltwater channels on shore, suggest that the major Weichselian ice flow along the northern coast was eastwards. This is difficult to reconcile with a glacial scenario involving penetration of the Inland Ice westwards towards Kap Morris Jesup, unless, of course, the region has been affected by several ice regimes with opposing ice transport directions. Alternatively, Funder (in press) has speculated that the crystalline erratics "might represent ancient detritus, the product of an epoch when the Inland Ice entirely covered the mountain range of northern Peary Land. Such a model demands that the younger, presumably local, glaciation has obliterated (either removed or buried) all such erratics from a vast area of Peary Land, while apparently preserving them only along one part of the outer coast.

Table 1. Summary of possible sources of northern Peary Land crystalline erratics

\begin{tabular}{|c|c|c|c|c|}
\hline \multicolumn{2}{|c|}{ Transport } & \multirow{2}{*}{ Provenance } & \multirow{2}{*}{ Main positive data } & \multirow{2}{*}{ Main negative data } \\
\hline By & From & & & \\
\hline \multirow{4}{*}{ 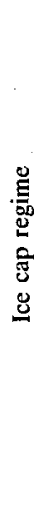 } & West & $\begin{array}{l}\text { Ellesmere } \\
\text { Island }\end{array}$ & $\begin{array}{c}\text { Ice-shelves off Ellesmere Island } \\
\text { and Greenland inferred from } \\
\text { other data and eastern ice flow } \\
\text { suggested by Funder \& Larsen } \\
\text { (1982) }\end{array}$ & $\begin{array}{c}\text { Crystalline complex composed of } \\
\text { larger diversity than present as } \\
\text { erratics }\end{array}$ \\
\hline & & \multirow{4}{*}{$\begin{array}{l}\text { Greenland } \\
\text { shield }\end{array}$} & $\begin{array}{l}\text { Eastern ice flow suggested by } \\
\text { Funder \& Larsen (1982) }\end{array}$ & $\begin{array}{c}\text { Lack of fossiliferous Lower } \\
\text { Palaeozoic erratics, east of } \\
\text { Nansen Land }\end{array}$ \\
\hline & South & & $\begin{array}{l}\text { Perhaps the most direct and } \\
\text { simplest transportation route }\end{array}$ & $\begin{array}{c}\text { Demands ancient Inland Ice } \\
\text { blanket to Arctic Ocean and } \\
\text { highly selective obliteration by } \\
\text { younger glaciation }\end{array}$ \\
\hline & & & $\begin{array}{l}\text { Distribution of crystalline } \\
\text { erratics from Independence }\end{array}$ & $\begin{array}{l}\text { Conflicts with data of Funder \& } \\
\text { Larsen (1982) }\end{array}$ \\
\hline \multirow{2}{*}{. } & Cast & & $\begin{array}{l}\text { decrease in abundance of } \\
\text { erratics westwards along } \\
\text { northern coast }\end{array}$ & $\begin{array}{l}\text { Demands consistent northerly } \\
\text { circulation in early Holocene sea }\end{array}$ \\
\hline & North & Eurasian coast & $\begin{array}{l}\text { Arctic Ocean circulation allows } \\
\text { for rafted lag deposit origin }\end{array}$ & $\begin{array}{l}\text { Lack of non-Greenland } \\
\text { Phanerozoic erratics }\end{array}$ \\
\hline
\end{tabular}




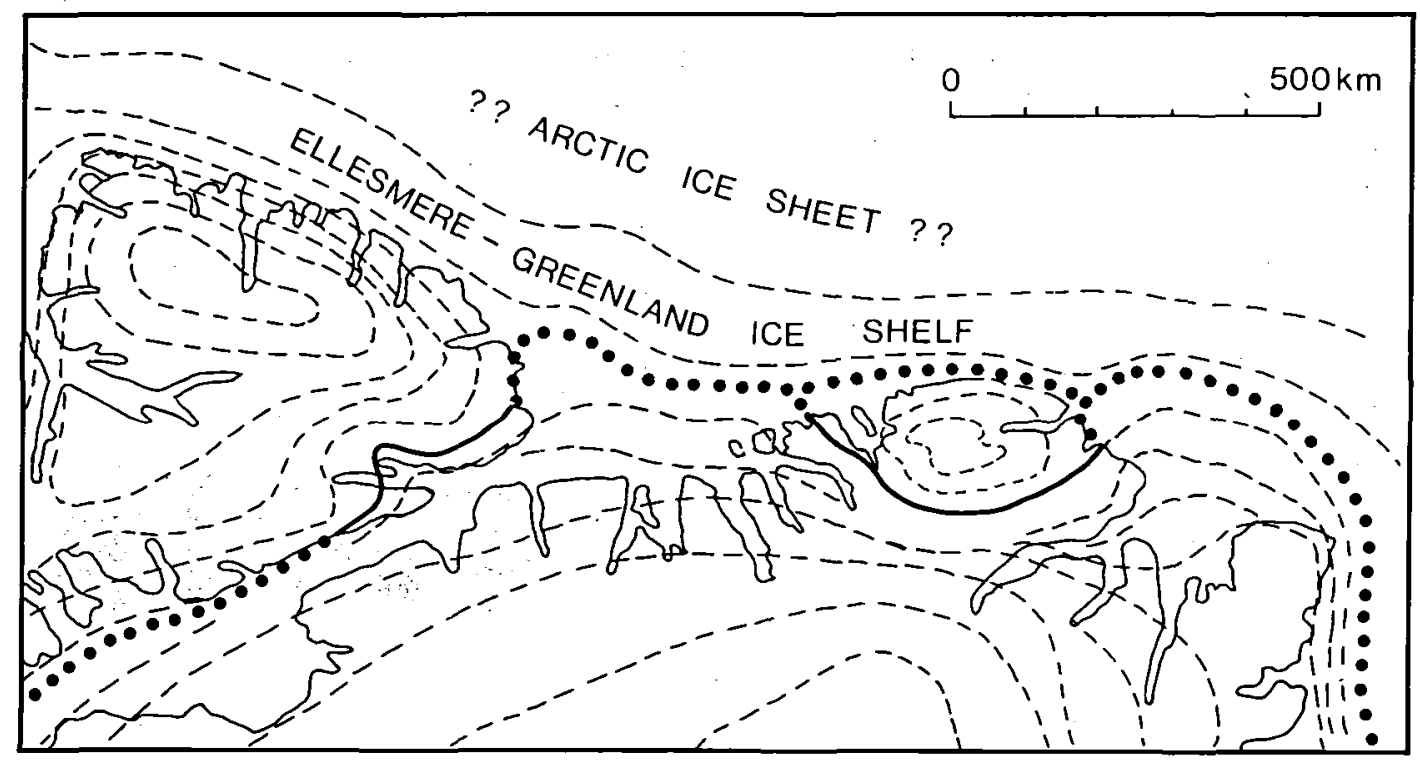

Fig. 5. Late Wisconsinian-Weichselian model showing extensive Ellesmere-Greenland ice-shelf and one possible derivation of Peary Land crystalline erratics. Dotted line: suggested limit of Greenland dominated ice-shelves; full line: established northern limit of Inland Ice; dashed lines: ice formlines modified from Weidick (1975).

The alternative model is that the erratics have been derived from the west. During the glaciation maximum the Inland Ice reached the Lincoln Sea where it presumably formed an ice-shelf (Figs. 2, 5). A heterogeneous erratic assemblage of southerly provenance characterised by distinctive fossiliferous Lower Palaeozoic carbonates, as well as crystalline rocks, occurs on southern Nansen Land and islands to the west (Koch, 1928a, b). Whether the ice totally covered northern Nansen Land is uncertain (Kelly \& Bennike, 1985), but easterly expansion along the coast may have occurred. However, fossiliferous sediments - a dominant clast type around the Lincoln Sea do not appear farther east along the coast; thus without invoking some sort of screening mechanism, eastern flow of the Inland Ice does not satisfactorily account for the erratic distribution.

On the other hand, a non-Greenland ice stream flowing eastwards outside the Lincoln Sea ice - as part of an extensive ice-shelf - could explain the selective occurrence of crystalline erratics east of Kap Morris Jesup. It may be significant that high-grade rocks in northern Ellesmere Island form the outermost part of the coast. Thus ice flowing from this region across the Lincoln Sea would not necessarily be charged with a heterogeneous erratic assemblage.

\section{Conclusions and the ice-shelf model}

As a batch the crystalline erratics show more mineralogical affinity to the Greenland shield than to the Ellesmere Island complex. However, an appropriate glacial flow pattern from the Inland Ice is difficult to reconcile with available data (Table 1). If it is assumed that the erratics represent a glacial deposit rather than detritus carried by floating ice, then a model involving transport from the west agrees with the recent work of Funder \& Hjort (1980) and Funder \& Larsen (1982). Derivation from the east - the most reasonable model based solely on till-clast distribution - necessitates either reappraisal of the interpretations of Funder \& Larsen or the invocation of a rather complicated glacial history involving different ice regimes and opposing ice transport directions along the coast.

${ }^{14} \mathrm{C}$ dating of marine shells (Funder, 1982) gives a minimum date for deglaciation of the outer coast of about $8500 \mathrm{~B}$. P. The late WisconsinianWeichselian model which appears to fit most of the available data, involves an extensive ice-shelf along the Greenland-Ellesmere margin, fed by ice masses on shore, and in which a strong westerly component existed (Fig. 5). Such an ice regime would not only provide a mechanism to ex- 
plain the distribution of crystalline erratics but might provide an answer to the question posed by Funder \& Larsen (1982) of why glaciers flowing from the Roosevelt Fjelde to the Arctic Ocean were deflected eastwards along the coast.

Essentially, ice-shelves are formed either by the seaward extension of land ice, or by the substantial thickening of sea ice held fast to the shore (Robin, 1979). Today, the only ice-shelf in the region is the Ward Hunt ice-shelf off northernmost Ellesmere Island (Fig. 1). This has developed primarily from sea ice cover, i.e. continued thickening due to surface accumulation and bottom freezing (Marshall, 1955; Hattersley-Smith et al., 1955; Crary, 1960). However, Hattersley-Smith (op. cit., p. 33) remarks that "previous ice shelves, of dynamic character and greater extent, may have existed along this coast in earlier, more intensely glacial times". The late WisconsinianWeichselian ice-shelf suggested here must have been of dynamic character, being fed by ice tongues from shore. It is interesting that part of the ice-shelf around Milne Fiord (Fig. 1) is also composed of glacier ice (Jeffries, 1985). Erratic blocks on the shelf ice there can be matched with rock complexes to the west indicating an easterly flow of glacier ice along the coast.

An extensive late Wisconsinian-Weichselian ice -shelf, characterised by an easterly flow direction along the northern coasts of Ellesmere Island and Greenland (part of the regional ice flow path from the Arctic Basin to the North Atlantic) may have been bordered to the north by a great ice sheet or floating ice caps, such as those proposed by Broecker (1975) and Hughes et al. (1977). This remains speculation. However, it is noteworthy that in the glacial reconstructions put forward by Denton \& Hughes (1981) and Mayewski et al. (1981) involving a late Wisconsinian-Weichselian Arctic ice sheet draining into the North Atlantic, ice from the Canadian sector shows flow lines from northern Ellesmere Island that pass close to the northern coast of Greenland.

Acknowledgements. Discussion with Svend Funder (Geological Museum) stimulated the preparation of this article for publication. I am grateful to him, Anker Weidick and Ole Bennike for critically reading the text; the latter supplied unpublished data on glacial erratic distribution. Information from William E. Davies (U. S. Geological Survey) on composition of stone counts is acknowledged. Fig. 4 is published by permission of the
Geodetic Institute, Copenhagen; the paper is published by permission of the Director, Geological Survey of Greenland. Thanks to Esben Glendal, Bente Thomas and Johan D. Friderichsen for technical assistance.

\section{Dansk sammendrag}

En lille samling af istransporterede blokke (gnejs, granit og amfibolit) fra Grønlands nordkyst i Peary Land stammer ikke fra de lokale bjergarter. Indlandsisen, som $i$ dag dakker det nærmeste potentielle oprindelsessted, grundfjeldsskjoldet, ligger $250 \mathrm{~km}$ fra blokkenes findested. Det lokale till blokselskab består af sedimentære og nogle få vulkanske bjergarter, som stammer fra en lokal iskappe. Denne var ved ca. $82^{\circ} 30^{\prime} \mathrm{N}$ forenet med indlandsisen under det glaciale maximum $\mathrm{i}$ Wisconsin istiden.

Samlingen stammer fra kyststrækningen mellem Kap Ole Chiewitz og Kap Morris Jesup og blev samlet i 1969. Den rummer en serie granitiske og granodioritiske bjergarter $i$ amfibolit facies og med metamorf-plutonisk affinitet. Gletscher- kontra drivis-transport såvel som mulige transportveje gennemgås.

Det grgnlandske grundfjeldsskjold og det nordlige Ellesmere Island er potentielle oprindelsessteder, og af disse er det grønlandske skjold i bedst overensstemmelse hvad angår bjergartstyper og mineralogi.

Glaciation øst om Peary Land forekommer mest logisk men modsiges af oplysninger fra Funder \& Larsen (1982), som indebærer en Weichselisk istransport langs kysten mod øst. En alternativ model opstilles, som ikke involverer flere istider og modsatrettede transportveje langs kysten, og som er baseret på en udbredt Grønland - Ellesmere Island shelf-is.

\section{References}

Bessels, E. 1879: Die amerikanische Nordpol-Expedition. Leipzig: Von Wilhelm Engelmann, $647 \mathrm{pp}$.

Broecker, W. W. 1975: Floating glacial ice-caps in the Arctic Ocean. Science 188, 1116-1118.

Christie, R. L. 1967: Reconnaissance of the surficial geology of northeastern Ellesmere Island, Arctic Archipelago. Bull. geol. Surv. Can. $138,50 \mathrm{pp}$.

Christie, R. L. 1975: Glacial features of the Børglum Elv region, eastern North Greenland. Rapp. Grønlands geol. Unders. 75, 26-28.

Clark, D. L. \& Hanson, A. 1983: Central Arctic Ocean sediment texture: a key to ice transport mechanisms. In: B. F. Molnia (ed.): Glacial-marine sedimentation, 301-330. New York: Plenum Publ. Corp.

Crary, A. P. 1960: Arctic ice islands and ice shelf studies, Part II. Arctic 13, 32-50.

Davies, W. E. 1963: Glacial geology of northern Greenland. Polarforschung 5, 94-103.

Dawes, P. R. 1970: Quaternary studies in northern Peary Land. Rapp. Gronlands geol. Unders. 28, 15-16.

Dawes, P. R. 1972: Quaternary studies in north Peary Land. In: J. D. C. Peacock (ed.): Joint Services expedition North Peary Land 1969, Annex B, part 11, B6-7. London: Ministry of Defence.

Dawes, P. R. 1986: Computer-supported topographical-geological mapping of Hall Land, North Greenland; description of photogrammetrical programme, physical, Palaeozoic . and Quaternary geology. Bull. Grønlands geol. Unders.

Dawes, P. R. \& Soper, N. J. 1973: Pre-Quaternary history of North Greenland. In: M. G. Pitcher (ed.): Arctic geology. Mem. Am. Ass. Petrol Geol. 19, 117-134. 
Denton, G. H. \& Hughes, T. J. 1981: The Arctic ice sheet: an outrageous hypothesis. In: G. H. Denton \& T. J. Hughes (eds.): The last great ice sheets, 437-467. New York: John Wiley \& Sons.

Ellitsgaard-Rasmussen, K. 1955: Features of the geology of the folding range of Peary Land, North Greenland. Meddr Gronland 127(7), $56 \mathrm{pp}$.

England, J. \& Bradley, R. S. 1978: Past glacial activity in the Canadian High Arctic. Science 200, 265-270.

Feilden, H. W. 1895: Note on the erratic blocks of Polaris Bay and other localities in North Greenland. Geol. Mag. New ser., Decade 4, 2, 378-379.

Frisch, T. 1974: Metamorphic and plutonic rocks of northernmost Ellesmere Island, Canadian Arctic Archipelago. Bull. geol. Surv. Can. 229, 87 pp.

Funder, S. 1982: ${ }^{14} \mathrm{C}$-dating of samples collected during the 1979 expedition to North Greenland. Rapp. Gronlands geol. Unders. 110, 9-14.

Funder, S. in press: North Greenland. In: R. J. Fulton (ed.) Quaternary: Canada and Greenland, DNAG volume K-1. Geol. Surv. Canada.

Funder, S. \& Larsen, O. 1982: Implications of volcanic erratics in Quaternary deposits of North Greenland. Bull. geol. Soc. Denmark 31, 57-61.

Funder, S. \& Hjort, C. 1980: A reconnaissance of the Quaternary geology of eastern North Greenland. Rapp. Grønlands geol. Unders. 99, 99-105.

Hattersley-Smith, G. et al. 1955: Northern Ellesmere Island, 1953 and 1954. Arctic 8, 2-36.

Henriksen, N. \& Jepsen, H. F. 1985: Precambrian crystalline basement at the head of Victoria Fjord, North Greenland. Rapp. Gronlands geol. Unders. 126, 11-16.

Hughes, T. [J.], Denton, G. H. \& Grosswald, M. G. 1977: Was there a late-Würm Arctic Ice Sheet? Nature, Lond. 266, 596-602.

Jeffries, M. O. 1985: Ice shelf studies off northern Ellesmere Island, spring 1983. Arctic 38, 174-177.

Kelly, M. \& Bennike, O. 1985: Quaternary geology of parts of central and western North Greenland: a preliminary account. Rapp. Grønlands geol. Unders. 126, 111-116.

Koch, I. P. 1916: Survey of Northeast Greenland. Meddr Grønland 46(2), 79-468.
Koch, L. 1920: Stratigraphy of Northwest Greenland. Meddr dansk geol. Foren. 5, 1-78.

Koch, L. 1923a: Resultaterne af Jubilæumsekspeditionen Nord om Grønland i 1921. Naturens Verden 7, 49-76.

Koch, L. 1923b: Preliminary report upon the geology of Peary Land, Arctic Greenland. Am. J. Sci. 5(27), 190-199.

Koch, L. 1928a: The physiography of North Greenland. In: M. Vahl, et al. (eds.): Greenland 1, 491-518. Copenhagen: C. A. Reitzel.

Koch, L. 1928b: Contributions to the glaciology of North Greenland. Meddr Grønland 65(2), 181-464.

Larsen, O. 1982: The age of the Kap Washington Group volcanics, North Greenland. Bull. geol. Soc. Denmark 31, 4955.

Marshall, E. W. 1955: Structural and stratigraphic studies of the northern Ellesmere ice shelf. Arctic 8, 109-114.

Mayewski, P. A., Denton, G. H. \& Hughes, T. J. 1981: Late Wisconsin ice sheets in North America. In: G. H. Denton \& T. J. Hughes (eds.): The last great ice sheets, 67-178. New York: John Wiley \& Sons.

Mikkelsen, E. 1922: Report on the Expedition. In: AlabamaExpeditionen til Grønlands Nordøstkyst 1909-1912 under ledelse af Ejnar Mikkelsen. Meddr Grønland 52(1), 142 pp.

Peacock, J. D. C. 1972: Joint Services Expedition, North Peary Land 1969. London: Ministry of Defence, $45 \mathrm{pp}$.

Robin, G de Q. 1979: Formation, flow, and disintegration of ice shelves. J. Glaciology 24, 259-271.

Soper, N. J., Higgins, A. K. \& Friderichsen, J. D. 1980: The North Greenland fold belt in eastern Johannes V. Jensen Land. Rapp. Gronlands geol. Unders. 99, 89-98.

Trettin, H. P. \& Balkwill, H. R. 1979: Contributions to the tectonic history of the Innuitian Province, Arctic Canada Can. J. Earth Sci. 16, 748-769.

Troelsen, J. C. 1952: Notes on the Pleistocene geology of Peary Land, North Greenland. Meddr dansk geol. Foren. 12, 211-220.

Weidick, A. 1975: A review of Quaternary investigations in Greenland. Rep. Inst. Polar Studies 55, $161 \mathrm{pp.}$

Weidick, A. 1976: Glaciations of northern Greenland - new evidence. Polarforschung 46, 26-33. 